\title{
The Detainee, the Prisoner, and the Refugee : The Dynamics of Violent Subject Production
}

\section{Nieminen, Kati}

2019-06

Nieminen , K 2019 , ' The Detainee, the Prisoner, and the Refugee : The Dynamics of

Violent Subject Production ' , Law, culture and the humanities , vol. 15 , no. 2 , pp. 516-539 . https://doi.org/10.1177/

http://hdl.handle.net/10138/308344

https://doi.org/10.1177/1743872116650868

unspecified

acceptedVersion

Downloaded from Helda, University of Helsinki institutional repository.

This is an electronic reprint of the original article.

This reprint may differ from the original in pagination and typographic detail.

Please cite the original version. 
Published in:

Law, culture and the humanities, 15(2), 516-539.

https://doi.org/10.1177/1743872116650868

The Detainee, the Prisoner, and the Refugee: The Dynamics of Violent Subject Production

\title{
Kati Nieminen
}

\begin{abstract}
This article takes violence in the law seriously, scrutinizing three sites engaged in violent subject production and resistance: the Guantanamo Bay detention center, supermax prisons in the US, and European refugee camps. The concepts of martyring and torturing serve help to untangle the dynamics of the law's violence. The violent subject production techniques used in these sites are discussed as torture practices that aim to reproduce the dominant subjectivity. As the law has often proved unable to fully address the situation of the detainee, the prisoner, and the refugee, hunger striking as martyring is discussed as a way to deconstruct hegemonic subjectivity and to force the law to face its own violence.
\end{abstract}

\section{Keywords}

Guantanamo Bay, supermax prison, refugee camp, subjectivity, detainee, prisoner, 


\section{PREPRINT}

Published in:

Law, culture and the humanities, 15(2), 516-539.

https://doi.org/10.1177/1743872116650868

refugee, torture, martyr, resistance, hunger strike, violence, law

\section{A I. Introduction}

Who gets banned and expelled so that we can live in reasonable consensus? Let us name them now. Criminals. Security Threats. Terrorists. Enemy Aliens. Illegal Immigrants. Migrant Contaminants. Unlawful Enemy Alien Combatants. Ghost Detainees [...] These are new orders of life; they hover outside the bounds of the civil, beyond simple dichotomies of reason and unreason, legal and illegal. ${ }^{1}$

What kinds of beings does the law create? What kinds of beings does it destroy? This article is based on the idea that the law is what the law does, and that it is worthwhile to take a closer look into what the law actually does besides providing answers to legally formulated questions. The main aim is to explore how the law violently calls subjects into being in the practices of the Guantanamo Bay detention center, in high security (supermax) prisons, and in European refugee camps, and how those subject production techniques are resisted. In short, I analyze the battle 
Published in:

Law, culture and the humanities, 15(2), 516-539.

https://doi.org/10.1177/1743872116650868

between the subjects as they know themselves and as the state wants them to know themselves.

Underneath these questions lies a bigger one: what is the relationship between the law and the state? The state and the (state's) law both presume each other. If the law is genuinely equated with what it does, the law and the state cannot be completely separated from each other. The state cannot escape the law; it cannot create places or operate outside the law, and thus it contributes directly to what the law in fact does. An illustrative example of how the law and the state are inseparably intertwined is the Guantanamo Bay detention center. Despite aspiring to create a place outside the law where it could operate without considering US law, the US government has created another kind of law, parallel to the law applied in US territories. All that takes place in Guantanamo takes place within a legal framework, not outside of it. ${ }^{2}$

It has long been recognized that the law in books is one thing, while the law in action is another. This approach, however, is restricted in that it seems to assume that if the law was applied by the book, the distinction would disappear and the law would be one. ${ }^{3}$ Besides its workings in books and in action, the law also does something else: it participates in creating the world we live in by producing meaning. Here I adopt a Derridean understanding of meaning production: language does not first and foremost transmit a particular message or a certain meaning; 
Published in:

Law, culture and the humanities, 15(2), 516-539.

https://doi.org/10.1177/1743872116650868

rather it reproduces and creates new interrelations between signs, thus generating new interpretations of the world. Moreover, the law need not be limited to its normative aspects or to the acts of certain agents over those of others; instead of being this rather than that, law can be both this and that at once.

The conception of law to which this article commits derives from such theorists as Colin Dayan, Scott Veitch, and Robert M. Cover, all of whom acknowledge the violent side of law. ${ }^{4}$ Dayan reminds us that there is no escape from law, even in places that are sometimes called legal black holes, such as Guantanamo, Abu Ghraib, and other secret detention centers throughout the world. ${ }^{5}$ According to Veitch, law and legal institutions are, contrary to common perception, central in deflecting responsibility from extensive human rights violations. For him, this is not due to the deficits in the substance of the law, but is an intrinsic feature of the law itself. ${ }^{6}$ A similar idea has been promoted by Cover, who claims that violent law is not a corrupt version of the law, but an inevitable, inseparable part of it, and that the law cannot remain innocent to atrocities committed in its name. ${ }^{7}$

By violence of the law, Cover means the law's tendency to reproduce itself and its subjectivities by destroying competing worlds; while the law reproduces some traditions, it kills others. ${ }^{8}$ Cover's argument resonates with Foucault's notion of epistemic violence and subjugated knowledge, that is, knowledge which is 
Published in:

Law, culture and the humanities, 15(2), 516-539.

https://doi.org/10.1177/1743872116650868

disqualified and deemed inferior to the dominant truth. ${ }^{9}$ In this article, the focus is on the battle over whose truth about the self persists.

Foucault's analysis of subject production contrasts power with force and violence. Power is subtle in that it seeks the collaboration of its subjects. In many subtle ways, power invites subjects to commit to reproducing themselves through practices of self-mastery. This individualizing power requires that subjects internalize the dominant truth about themselves and reproduce it with techniques that aim to self-mortify (i.e. self-renounce). According to Foucault, even when overwhelming, power is never absolute; there is always room for resistance. ${ }^{10}$ While power relations can only be exercised over free subjects, violence "acts upon a body or upon things; it forces, it bends, it breaks on the wheel, it destroys, or it closes the door on all possibilities." ${ }^{11}$ Violent subject production takes place in the intersection between power and violence: despite the subjection of the detainee, the prisoner and the refugee to various physically and mentally violent practices, their treatment does not ultimately aim at crushing their existence as human beings, but instead at making them adopt a new truth about themselves.

The dynamics of violent subject production are discussed in this article using the terms torturing and martyring. By torture I mean the techniques used in closed facilities that violently produce subjects, and which aim to destroy the victim's world as they know it. Thus torture refers not to, nor is it identical to, any of the 
Published in:

Law, culture and the humanities, 15(2), 516-539.

https://doi.org/10.1177/1743872116650868

legal definitions of torture. Rather, the torturer aims to destroy 'the victim's normative world and capacity to create shared realities" and is designed to demonstrate the end of their normative world, "the end of what the victim values, the end of the bonds that constitute the community in which the values are grounded."12 The battle is ultimately about whose reality, whose truth, and whose world survives. The martyr, on the other hand, "insists in the overwhelming force that if there is to be continuing life, it will not be in terms of the tyrant's law. [...] Martyrs require that any future they possess will be on the terms of the law to which they are committed. And the miracles of the suffering of the martyrs is their insistence on the law to which they are committed, even in the face of worlddestroying pain. [...] Martyrdom is an extreme form of resistance to domination. [...] A legal world is built only to the extent that there are commitments that place bodies on the line."13

Here, resistance does not target an institution, but power techniques which impose a certain kind of subjectivity on the individual. With their bodies, martyrs resist internalizing the dominant truth, which is the truth about themselves as deviants. By portraying hunger striking as martyring, I do not wish to glorify martyring or to claim that it is an act of an ideal political subject, nor do I believe it to be the most effective mode of resistance regarding changing state policies. Rather, I claim that martyring is a way of not giving up on one's own truth about oneself and, as such, 
Published in:

Law, culture and the humanities, 15(2), 516-539.

https://doi.org/10.1177/1743872116650868

is an act which forces the law to face its own violence.

By refusing to eat, hunger strikers refuse the subjectivity imposed on them, thereby bringing the possibility of death to the heart of their relationship with the state. ${ }^{14}$ Hunger strikers deconstruct their legal subjectivity; they are willing, literally, to let the subject die along with their own bodies. Because hunger strikers refuse to address the law with language recognizable to the law, the law cannot address them back; they are deaf to the law's interpellation. ${ }^{15}$ The law can only decide whether to let the body of the hunger striker die. ${ }^{16}$

This article is divided into four main sections and a concluding section. First, the production of the subjectivities of the detainee, the prisoner, and the refugee is discussed as a means of bringing the individuals placed in the Guantanamo Bay detention center, the supermax prison, and refugee camps into being as subjects to power. Secondly, the practices that are here called torture, are discussed in more detail in each of the three sites. The two subsequent sections discuss the legal and extra-legal resistance strategies adopted by the individuals, especially paying attention to hunger striking as a means of revealing the violent side of the law and as an alternative to legal channels in challenging the fundamental aspects of violent subject production practices. 
Published in:

Law, culture and the humanities, 15(2), 516-539.

https://doi.org/10.1177/1743872116650868

A II. Subject production in the Guantanamo, the supermax, and the refugee camp

What kinds of subjects inhabit the Guantanamo Bay detention center, the supermax prison, and refugee camps? The three sites form an interesting triangle of subjectification. While it is important to acknowledge the differences between the contexts and the legal status of the detainee, the prisoner, and the refugee, the subject production practices in the three sites have significant resemblances.

The prison is an iconic site of subject production, an arena in which the state asserts its power both to define the limits of citizenship and to confine those who deviate from that designation. In prison, the deviant, pathologized subject is corrected and rehabilitated, stored, and fit into the frame of a manageable deviant subject. ${ }^{17}$ Ultimately, subject production is part of the production and maintenance of the state itself. ${ }^{18}$

Although the supermax prison as a penal institution and the Guantanamo Bay detention center as a military institution obviously differ, they both operate with the same logic of subject production: both are arenas where the battle rages over whose world and whose truth will survive. ${ }^{19}$ Despite becoming part of the mass population, the detainee or the prisoner as an individual does not lose their 
Published in:

Law, culture and the humanities, 15(2), 516-539.

https://doi.org/10.1177/1743872116650868

importance to the state. In refugee camps, however, this is exactly what happens; unlike in prison, the refugee is not the target of rehabilitation techniques, and the process does not aim to (re)integrate them into society, and unlike in Guantanamo, the aim is not to transform immigrants into docile and useful collaborators of the dominant regime. The refugee camp parallels the prison in that they can both be described as storage facilities for a so-called waste population. ${ }^{20}$ But the subject production process is different in the prison and in the camp: the prison is the ultimate site for producing manageable deviant subjects, whereas the camp simply restores people who are stuck in the limbo between being inside and outside of society.

What is common to the detainee at Guantanamo and the prisoner in the supermax is danger - both are by default designated as dangerous to the rest of society, both are subject positions that are per se considered deviant. The refugee, on the other hand, is different from the detainee and the prisoner in that the refugee is, as an individual, irrelevant to the state. Therefore, as an individual feature, the aspect of danger is lacking from the refugee subjectivity. However, as discussed in the concluding section, this may be changing in Europe as refugees are increasingly suspected of potential terrorism, as well as being perceived as a growing economic and social threat.

The subject production techniques that are here called torture are all supported by 
Published in:

Law, culture and the humanities, 15(2), 516-539.

https://doi.org/10.1177/1743872116650868

the law, either officially or unofficially. The torture techniques include the enhanced interrogation techniques at Guantanamo Bay; solitary confinement, debriefing, and the Step Down policy in the supermax; and the poor living conditions and practices that effectively block access to justice both inside and outside of refugee camps.

Both at Guantanamo Bay and the supermax, the inmates are first subjected to mortification practices generally used in prison environments: they are stripped of their individuality by shaving their heads and facial hair, dressed in a uniform, and stripped of their names. Mortification practices explain how those with power are able to overcome the natural resistance to inflict pain on other individuals. ${ }^{21}$ Agamben has regarded the depersonified Guantanamo detainees as modern-day Homo Sacer, bare life - individuals stripped of citizenship and legal identity - and compared them in this respect to the Jews in Nazi camps. Indeed, the detention center has been described as a non-place similar to the concentration camp: a place outside the law, a legal black hole, and a prison beyond the law. ${ }^{22}$ Similarly, the detainees have been described as legally unclassifiable and unnamable beings; they are not prisoners of war under the Geneva Convention nor have they been charged with a crime under US laws. Instead, they are simply detainees, with reduced legal subjectivity.

In its original ancient form, Homo Sacer meant being cast outside the law in the 
Published in:

Law, culture and the humanities, 15(2), 516-539.

https://doi.org/10.1177/1743872116650868

sense that the law no longer protected that person. This meant that the state treated them with indifference, and that they could be killed with impunity. ${ }^{23}$ However, the prisoner at the supermax and the detainee at Guantanamo have not become bare life in the sense that the law treats their existence as individuals with indifference, quite the contrary. The prisoners and especially the detainees have, arguably, been the subject of extensive work on legal classification and regulation requiring a special set of techniques to process them as individuals. ${ }^{24}$

Law's relationship with the refugee subject is different from its relationship with the detainee and the prisoner, who are defined by danger. The resistance strategies adopted by the detainee and the prisoner ultimately target precisely this aspect of their subjectivity, as it is the decisive feature justifying their treatment as less than human. Refugees, on the other hand, have not been touched by the law in the sense that they have not been, before processing their individual cases, recognized by the law as individuals. While the detainee and the prisoner struggle to be seen differently by the law, the refugee struggles to be recognized as somebody by the law. These struggles are illustrated in the following sections by discussing the violent subject production techniques used in the three sites on the one hand, and the legal and extra-legal resistance strategies adopted by the detainee, the prisoner, and the refugee, on the other. 
Published in:

Law, culture and the humanities, 15(2), 516-539.

https://doi.org/10.1177/1743872116650868

\section{A III. Torture practices}

\section{Enhanced interrogation techniques}

They pull you apart and put you back together, dismantling into smaller pieces each time, until you become something different, their creation, when eventually reassembled. [...]Interrogators worked around the clock to break us. Once broken, detainees were asked to agree to anything by interrogators, to repeat after them, to sign confessions, to be false witnesses, or to sow discord amongst detainees. ${ }^{25}$

Since 2002, the US has used the Guantanamo Bay naval base as a detention center for individuals captured from all over the world in the war on terrorism. ${ }^{26}$ Following the terrorist attacks of September 11, 2001, congress passed the Authorization to Use Military Force, which granted the President the authority to "use all necessary and appropriate force" against those who had committed or aided the terrorist attacks. The legal status of these individuals, who have been deemed enemy combatants, has developed in a dialogue between the US administration and Supreme Court rulings. ${ }^{27}$ The situation of the Guantanamo detainees is complicated with conflicting rulings, overlapping legal sources, and practical difficulties.

Despite, or because of, all the law and cases concerning Guantanamo, 103 men 
Published in:

Law, culture and the humanities, 15(2), 516-539.

https://doi.org/10.1177/1743872116650868

were still being held in indefinite detention in January 2016, even though many of them were cleared for release a long time ago. ${ }^{28}$

The so called enhanced interrogation techniques were introduced in the aftermath of September 11, 2001 and used, besides at Guantanamo, in multiple other detention sites operated by US officials all over the world. The interrogation techniques were approved by the Department of Justice's Office of Legal Counsel in various memoranda. The approved techniques included e.g. sleep deprivation for up to 72 hours, reduced caloric intake, the use of loud music or white noise, the use of diapers "generally not to exceed 72 hours," attention grasps, facial and abdominal slaps, cramped confinement in a dark box for up to 18 hours, the combination of cramped confinement with the use of insects, various stress positions, sleep deprivation for up to 11 days, and the waterboarding technique. ${ }^{29}$

The use of the so called enhanced interrogation techniques was legally justified based on the assumption that the detainees represented an imminent danger to the US. The detainees were considered organized and trained to conduct terrorist attacks and resist various interrogation techniques, and to possess knowledge about terrorist attacks in the making. Despite the explicit aim of eliciting "actionable intelligence," the enhanced interrogation techniques were more effective in creating a new kind of subjectivity. In fact, the combination of interrogation and torture is rarely designed to elicit information to begin with. The point instead is to make the 


\section{PREPRINT}

Published in:

Law, culture and the humanities, 15(2), 516-539.

https://doi.org/10.1177/1743872116650868

detainees resign their own truth and adopt, or at least acknowledge the superiority of, the dominant truth. ${ }^{30}$

The torture procedures, which ultimately aim at the individual adopting a new subjectivity, resemble the logic of knowledge production in the Foucauldian sense; the dominant truth is reproduced through confession, a ritual in which the detainees give up their deviant version of the truth. Confession therefore has value not as information, but as a demonstration of submission. According to Scarry, "[i]n confession one betrays oneself and all those aspects of the world [...] that the self is made up of. $[\ldots][\mathrm{I}] \mathrm{t}$ is for this reason that while the content of the prisoner's answer is only sometimes important to the regime, the form of the answer, the fact of his answering, is always crucial." 31 A similar logic can be seen in the debriefing and Step Down policies exercised in the Californian supermax prisons, which are discussed in the following section.

A few months in the solitary cell renders prisoners strangely impressible. The chaplain can then make the brawny navy cry like a child; he can work on his feelings in any way he pleases. He can [...] photograph his thoughts, wishes, and 
Published in:

Law, culture and the humanities, 15(2), 516-539.

https://doi.org/10.1177/1743872116650868

opinions on his patient's mind, and fill his mouth with his own phrases and language. ${ }^{32}$

California has four prisons, one of which is the Pelican Bay State Prison in Crescent City, which has a Security Housing Unit (SHU) where some inmates are segregated from other prisoners. The Pelican Bay and Sacramento State Prisons also have Psychiatric Service Units (PSU). California currently holds approximately 3500 to 4000 prisoners in SHUs, and 300 in PSUs. Approximately a quarter to half of the prisoners in these institutions are placed in SHUs. The majority of the inmates in SHUs are male, and Latinos are over-represented among them. Being placed in a security housing unit (SHU) in a Californian prison requires that one has been deemed dangerous in some way. ${ }^{33}$ Officially, security housing units are "designed to house the State's most serious criminal offenders in a secure, safe and disciplined institutional setting" and neither "designed nor intended as punishment for misbehavior." 34 Inmates can be placed in a SHU for six months to five years for violent offences committed in prison or indefinitely for being a validated gang member or associate. Currently, 107 inmates in California have served more than 20 years in an SHU, 303 have served more than 10 years, and 574 have served more than 5 years. ${ }^{35}$ Of those who have been placed in an 
Published in:

Law, culture and the humanities, 15(2), 516-539.

https://doi.org/10.1177/1743872116650868

SHU indefinitely, approximately $21 \%$ are validated gang members, and $79 \%$ are associates. $^{36}$

The logic of the security unit is one of isolation. Prisoners in SHUs are isolated from other prisoners, from prison staff, and from their family and friends. A prisoner placed in an SHU typically spends 23 hours a day in a cell which is lit at all times. They are permitted to exercise in an indoor recreation cell for one hour a day. The number of personal items, such as books and photographs, is limited. ${ }^{37}$ The defining element of solitary confinement is to minimize socially and psychologically meaningful interaction. Any available stimuli are usually monotonous, and existing social contacts lack empathy. Besides causing different physical and psychological effects, isolation is also an effective way to communicate to the prisoner that they have no power over themselves. ${ }^{38}$ Being released from indefinite solitary confinement requires that the prisoner assumes the subjectivity of a dangerous individual who must confess and repent in order to end the isolation. This process is called debriefing.

The prisoners themselves admit essentially having only two options: to debrief or to die. In debriefing, the prisoners in SHUs who are identified as either gang members or associates must denounce all relations with gangs. The process consists of two steps: an investigative phase and an observation phase. The purpose of the 
Published in:

Law, culture and the humanities, 15(2), 516-539.

https://doi.org/10.1177/1743872116650868

investigative phase (i.e. interview) is "to provide staff with information about the gang's structure, activities and affiliates" and to assess, among other things, the inmate's sincerity. Reviews of the continued need for solitary confinement occur every six years. ${ }^{39}$

Recently, the California Department of Corrections and Rehabilitation launched a new "behavior-based" Step Down policy for identifying prison-based gang members and associates, and isolating them in SHUs. ${ }^{40}$ The gangs (i.e. the Security Threat Groups, STGs) are classified into three sub-groups according to the estimated threat level they pose to the security of the institution. STG-I, which represents the most severe threat, includes gangs such as the Aryan Brotherhood, the Black Guerilla Family, the Mexican Mafia, and the Nazi Low Riders. ${ }^{41}$ The idea of the Step Down program is essentially identical to that of debriefing. In the Step Down program, the prisoner demonstrates in five steps their "willingness to disengage from criminal gang behavior" and gradually earns certain privileges, such as more phone calls to relatives, permission to participate in courses, an increase in the maximum number of personal items, such as photographs, more opportunities to interact with other inmates, and finally permission to rejoin the general prison population. At any moment during the program, prisoners can be returned to a previous step until "they demonstrate a desire and behavior for movement into the next step." The successful completion of each step requires at 
Published in:

Law, culture and the humanities, 15(2), 516-539.

https://doi.org/10.1177/1743872116650868

least 12 months. ${ }^{42}$

According to the think tank New Afrikan Revolutionary Nationalism (NARN), to successfully complete the Step Down program, "you must be willing to accept and believe all of the absolute worst things that the state has said about us all and continues to say - and to invalidate yourself completely." ${ }^{\text {43 }}$ From the point of view of the SHU inmate, debriefing and Step Down are violent processes of subject production in which prisoners must denounce their sympathies for the people, ideas, and lived experiences with which they identify. Debriefing and Step Down are examples of governmental techniques which, according to Garland, assume that rational actors can be manipulated to align their preferences with those of the governing authorities and to self-regulate in a way that feels freely chosen. Incentives and disincentives teach the prisoner to engage with institutional goals and to reflect them in their behavior. ${ }^{44}$ Inmates are forced into assuming a dangerous subjectivity in a process similar to that of confession: the inmate confesses their associations with deviants and re-establishes loyalty to the official regime. Again, as in using enhanced interrogation techniques, obtaining useful security information is only a secondary goal.

Moreover, the release of SHU inmates into the general prison population fits with Foucault's two principal uses of prisoners: firstly, prisoners, when released back into the general population, are useful as informants for the police, because they 


\section{PREPRINT}

Published in:

Law, culture and the humanities, 15(2), 516-539.

https://doi.org/10.1177/1743872116650868

provide the authorities with access to the underworld; secondly, released inmates moralize the working class, as they represent "the other" with whom the workers do

not wish to identify. ${ }^{45}$ Similarly, releasing the SHU inmates back into the general prison population after debriefing maintains conflict between inmates and prevents them from developing unwanted solidarity, as the former SHU inmate is known to have betrayed himself and others like him during the debriefing process.

Next, I move on to discuss the refugee subjectivity produced in the practices of "official indifference." 46 Unlike the detainee and the prisoner, the refugee is not the target of rehabilitation, reintegration or collaboration. Instead, they struggle with being dissolved into an anonymous mass in the eyes of officials. Nevertheless, the violence of subjectification they face is no less powerful.

Anyone will do whatever it takes to get his freedom. Some people tried to commit suicide to get free, others went crazy in there. ${ }^{47}$

Law's relationship with the refugee differs from the detainee and the prisoner, who 
Published in:

Law, culture and the humanities, 15(2), 516-539.

https://doi.org/10.1177/1743872116650868

are defined by their dangerousness as individuals. The current refugee situation in Europe offers insight into the way in which the law actually does become indifferent regarding the individual, who is consequently dissolved into an anonymous mass. Agamben points out that "every time a refugee represents not individual cases, but - as happens more and more often today $-[\ldots]$ a mass phenomenon, [the UN] organizations and individual states prove themselves, despite their solemn invocation of the 'sacred and inalienable' rights of man, absolutely incapable of resolving the problem and even confronting it adequately. ${ }^{48}$ Refugees are even discussed in terms that obscure the individual human being; they are "the mindless and unstoppable flood of human misery." 49

During the last couple of years, Europe has faced dramatically increased numbers of people from the Middle East, particularly from Syria, seeking international protection. ${ }^{50}$ Between April 2011 and November 2015, over 800,000 asylum applications were filed by Syrian refugees in European countries. Alongside Syria, most refugees coming to Europe originate from Afghanistan and Iraq. An increasing number of refugees take their chances in the Mediterranean Sea, many of them in unseaworthy boats and dinghies. In 2015 there were over million arrivals by sea, predominantly in Greece, and approximately over 3700 died or went missing in the sea. ${ }^{51}$ In many places in Europe, refugees are merely managed, and many of them are living in inadequate conditions and are vulnerable to exploitation. 
Published in:

Law, culture and the humanities, 15(2), 516-539.

https://doi.org/10.1177/1743872116650868

Within the European Union, Greece has for years been an internal buffer zone, as attempts have been made to limit the number of people crossing the European border by, for example, employing enhanced patrolling and surveillance, and by partially fencing Greek borders. In addition, controversial practices such as pushbacks and round-ups have been used to control immigration and to "clean up the streets" of Athens. ${ }^{52}$

Many other European Union countries have reintroduced border checks and have even partially fenced their borders in order to reduce the number of refugees entering. ${ }^{53}$ Many European refugee camps lack basic necessities such as proper food, shelter, and sanitation. Some camps have become centers where residents are "lost and forgotten" by the system; in Bulgaria, for example, the authorities do not register the people in the Harmanli camp as asylum seekers, and no one is in charge of the process. ${ }^{54}$ Although the camps are intended as temporary holding points, in many places, staying in the camp has become a permanent state with no realistic possibility for a fair, legal immigration process. ${ }^{55}$

According to the European Union Asylum Procedures Directive, ${ }^{56}$ asylum seekers should not be detained solely for entering the country without authorization, but reports cite asylum seekers in places such as Greece being systematically detained for irregular entry. In practice, pre-removal detention is more the rule than the exception in many European countries. ${ }^{57}$ The UN Working Group on Arbitrary 
Published in:

Law, culture and the humanities, 15(2), 516-539.

https://doi.org/10.1177/1743872116650868

Detention and the Committee against Torture have also expressed concern over the frequent failure to properly register unaccompanied minors and their systematic detention. While immigration detention is not intended as a punishment, many detained asylum seekers are subjected to similar treatment as criminal suspects and offenders, and in many places immigration detention has acquired an increasingly punitive nature. ${ }^{58}$ The length of detention varies, but is limited to 18 months in the European Union Returns Directive. ${ }^{59}$ In contrast, the UK has opted out of the directive and may practice indefinite detention, and in early 2014, the Greek legal council issued an advisory opinion allowing police to extend the length of detention beyond 18 months and potentially indefinitely in cases where detainees refuse to co-operate in their removal proceedings. ${ }^{60}$

The immigrant detention camps in Greece have been criticized for various failures by NGOs, the European Committee for the Prevention of Torture and Inhuman or Degrading Treatment or Punishment, the European Court of Human Rights, and the UN Special Rapporteur on torture and other cruel, inhuman or degrading treatment or punishment for both procedural problems and poor conditions, such as overcrowding, poor hygiene, lack of outdoor access, and lack of information on their rights. ${ }^{61}$ The Greek asylum procedure has been described as dysfunctional: filing claims of asylum has been made difficult, and reports indicate that the police have actively prevented asylum seekers from filing their claim or have ignored their 
Published in:

Law, culture and the humanities, 15(2), 516-539.

https://doi.org/10.1177/1743872116650868

requests to apply for asylum. ${ }^{62}$ Although the conditions at refugee camps are a partial result of the inability to accommodate large numbers of people seeking international protection and indifference to their needs, there is also a purposeful feature to it: the conditions are meant to communicate to potential immigrants that life in Europe is not desirable and to discourage them from coming. ${ }^{63}$

Bordering the European Union, Turkey is an important channel for refugees entering Europe. Turkey currently hosts over 261,000 refugees in 25 camps, and an unknown number of people live outside of camps. Access to information, registration, and public services is acutely limited. In order to deter the refugees from entering Europe the European Union and Turkey agreed in March 2016 that "all new irregular migrants crossing from Turkey to the Greek islands as of 20 March 2016 will be returned to Turkey", and that for every Syrian being returned to Turkey, another Syrian will be resettled to the EU.

For as long as refugees are unable to call on the law to recognize them, they are invisible to the law as individuals, despite the crowding in refugee camps. To the refugees, the law appears deaf and excruciatingly slow to grant recognition; the law also seems schizophrenic: on one hand it promises individual asylum processes and protection, but on the other hand it is reluctant to acknowledge their existence at all. 
Published in:

Law, culture and the humanities, 15(2), 516-539.

https://doi.org/10.1177/1743872116650868

The European situation has many contemporary and preceding parallels, ${ }^{64}$ but for the purposes of this article, the most interesting of them is Guantanamo Bay, which served as a detention site for over 12,000 Haitian refugees fleeing a military coup at the beginning of the 1990s. Even then, Guantanamo's convenient geographic location was not the main reason for establishing camps there; while under US control, Guantanamo was not actually inside the United States, which in practice undermined the refugees' access to due process. Guantanamo Bay was intended to serve as a "buffer zone" preventing the refugees from reaching US territory. The Haitian refugees were classified according to their ability to convince the migration officers of a "credible fear" of persecution. Some of them were returned to Haiti, while the ones successful in their claim for protection were transferred to the US mainland to undergo further assessment. ${ }^{65}$

Guantanamo Bay also became a detention site for Haitians who tested positive for HIV. In the case of Haitian Centers Councilv. Sale ${ }^{66}$, the US District Court ordered that HIV-positive detainees be brought into the US. The ruling did not, however, affect the legality of the immigration detention center in Guantanamo, which continued to be used for detaining asylum seekers from Haiti and Cuba. ${ }^{67}$ Some refugees at Guantanamo Bay contested the legality of the restrictions on access to lawyers in the camps, the camp conditions, and the legitimacy of indefinite detention without access to justice in US courts on several occasions, sometimes 


\section{PREPRINT}

Published in:

Law, culture and the humanities, 15(2), 516-539.

https://doi.org/10.1177/1743872116650868

with some success. The government, however, consistently insisted that the refugees were not entitled to the rights guaranteed under US law simply because they were outside US territory. ${ }^{68}$ As the state is not, as argued above, able to escape the law or to create extra-legal territories, the law in situations such as these becomes a tool to create, not exceptions, but parallel legal realities with reduced subject positions for the Other.

At the intersection of power and violence, there is still room for resistance. In the following, the resistance strategies adopted by refugees, detainees, and prisoners are discussed in more detail. The analysis is not intended to be exhaustive, but rather illustrative of the possibilities for resistance within the legal framework and their inevitable deficiencies as means for fundamental change in state practices. Hunger striking, for example, is discussed as a way of renouncing the legal language and restoring one's own understanding of oneself. Hunger striking and judicial litigation are often two parallel processes, sometimes even with similar objectives, but with fundamentally different possibilities, messages, and effects. ${ }^{69}$ 
Published in:

Law, culture and the humanities, 15(2), 516-539.

https://doi.org/10.1177/1743872116650868

Greece's incapacity to ensure an appropriate asylum procedure was recognized by the European Court of Human Rights in the case of M.S.S. v. Belgium and Greece (2011). ${ }^{70}$ The Dublin II Regulation ${ }^{71}$ determines which EU member state is responsible for the examination of an asylum application lodged in one of the member states by a third-country national. Primarily, the application is examined in the country where the asylum seeker has first entered the European Union area. In the case M.S.S., an asylum seeker was sent from Belgium to Greece, as that is where he had first entered the union. In Greece he was placed in detention twice, during which he was subjected to degrading detention circumstances: the detention facilities were overcrowded and lacked clean water, sanitation, and mattresses. After being released from detention, he lived on the streets without any support from the Greek government. The main question was whether Belgium was allowed to transfer the applicant back to Greece, where the problems faced by the asylum seekers were systemic and well documented. According to the court, Belgium had violated Article 3 (prohibition of torture and inhuman or degrading treatment) of the European Convention on Human Rights by exposing the applicant to the risks of the deficient asylum procedure and inadequate living conditions in Greece. According to Gina Clayton, the case was groundbreaking in that the general living conditions facing M.S.S., who was one of thousands, were considered inhuman and degrading treatment. ${ }^{72}$ 
Published in:

Law, culture and the humanities, 15(2), 516-539.

https://doi.org/10.1177/1743872116650868

In principle, the law protects the refugee from inefficient asylum procedures and degrading conditions in individual cases, but in practice, the law continues to allow refugees to be abandoned in the streets and "richer western European member states [to] continue to shift their responsibility to overburdened southern European member states". ${ }^{73}$ The law's role in resistance is inevitably ambivalent. A similar ambivalence can be detected in the cases of supermax prisoners and Guantanamo Bay detainees who have successfully challenged some of the practices of the government through legal channels, but whose position nevertheless has remained fundamentally unchanged. In 2012, on behalf of prisoners who spent 10 to 28 years in solitary confinement, the Center for Constitutional Rights filed a lawsuit against the State of California for its use of prolonged solitary confinement in Pelican Bay prison. The class action Ashker v. Brown challenged the prolonged solitary confinement and deprivation of a meaningful review process based on the rights guaranteed under the $8^{\text {th }}$ and $14^{\text {th }}$ Amendments of the US Constitution.

The Ashker case was settled in September 2015. According to the Center for Constitutional Rights, the settlement “transforms California's use of solitary confinement from a status-based system to a behavior-based system," introducing a two-year Step Down procedure. Moreover, all prisoners who had been in solitary confinement for over ten years were to be released into the general prison 


\section{PREPRINT}

Published in:

Law, culture and the humanities, 15(2), 516-539.

https://doi.org/10.1177/1743872116650868

population. California must also create a new Restricted Custody General Population Unit as an alternative to solitary confinement. ${ }^{74}$ Despite these reforms, it seems that there will be no fundamental changes in the logic of debriefing and Step Down, and the subjectivities they produce.

While the Guantanamo Bay detainees have been successful in establishing the jurisdiction of the US courts over the detention center, despite its location in Cuban territory (Rasul v. Bush 2004) ${ }^{75}$, and in establishing the rights to due process (Hamdi v. Rumsfeld 2004 ${ }^{76}$; Hamdan v. Rumsfeld $2006^{77}$; Boumediene v. Bush $2008^{78}$ ), nothing has prevented the detainees from being held in indefinite detention, without being charged with or convicted of a crime, but also without the hope of ever being released. This is what the law has become to them.

\section{A V. Martyring}

As an alternative to resistance through legal channels, hunger striking can be seen as a way of rejecting the subjectivity of a detainee or a prisoner, subjectivities which are restrained by the perception of danger and threat, and reduced in the sense that they do not, by default, possess all the legal rights granted for the citizen subject. Patrick Anderson has studied the Turkish hunger strikes at high security 
Published in:

Law, culture and the humanities, 15(2), 516-539.

https://doi.org/10.1177/1743872116650868

prisons as an attempt to establish hunger striking as a viable, sustainable form of political action and of the production of new kinds of political subjects. ${ }^{79}$

On October 20, 2000 in Turkey began what would become the longest and most deadly hunger strike in modern history. The strike went on for three years with more than 2000 people, of whom 107 died. The hunger strikers protested against the transfer of political prisoners to F-type prisons that were designed to isolate prisoners and to limit or deny interaction between them, which also made it easier for torture and ill-treatment to go unnoticed. The hunger strikers demanded immediate and unconditional repeal of the Anti-Terror Law, independent monitoring of prisons and the treatment of prisoners, the release of prisoners suffering from permanent injury or illness as a result of previous hunger strikes, and trials for prison staff and others accused of torturing the prisoners. ${ }^{80}$

Despite hunger strikers aiming at these concrete improvements, it would be a mistake to see their struggle strictly in terms of presenting a list of demands. ${ }^{81}$ Anderson argues that the Turkish hunger strikes function as a performance to refigure the relationship between the state and the subject, and to introduce a new kind of political subjectivity. ${ }^{82}$ The F-type prison, similarly to Guantanamo and the supermax, was created for the "worst of the worst," for the dangerous subject. It can be argued that the supermax hunger strikers challenged precisely the aspect of danger attached to them. They, as the prisoners in the Turkish equivalent to the 
Published in:

Law, culture and the humanities, 15(2), 516-539.

https://doi.org/10.1177/1743872116650868

supermax, perceive themselves as being punished not only for crimes, but for their political views - not only for what they have done, but for who they are.

The Ashker case was part of a larger movement to reform the conditions in SHUs, which, interestingly, was sparked by hunger strikes by thousands of SHU prisoners in 2011 and $2013 .{ }^{83}$ The plaintiffs in the case participated in hunger strikes in protest against the gang validation process preceding indefinite solitary confinement. ${ }^{84}$ According to the Pelican Bay hunger strikers, inmates can be assigned to a SHU with no significant disciplinary record based on alleged gang affiliation, which, in turn, can be based on vague, insignificant, and arbitrary evidence. ${ }^{85}$ Some supermax inmates confined in SHUs claim that they were validated as gang members or associates merely because of their political views and activities, and that the Departmental Review Board advised them to refrain from political writings. ${ }^{86}$ The Pelican Bay hunger strike in 2013 spread to 13 other state prisons and, at its peak, involved tens of thousands of people incarcerated in California. $^{87}$

Perceived dangerousness is also the explicated reason for detaining terrorist suspects at Guantanamo. In practice, legal channels for contesting the detention have been ineffective for most of the detainees, and with no other way to establish their own interpretation of themselves, hunger strikes, as well as suicide attempts, 
Published in:

Law, culture and the humanities, 15(2), 516-539.

https://doi.org/10.1177/1743872116650868

have been a regular occurrence among the detainees. ${ }^{88}$ The hunger strikers have demanded treatment in a manner consistent with the Geneva Conventions, better living conditions, respectful treatment of the Quran by guards, fair trials, and freedom. The longest hunger strike was initiated in 2005 by Abdul Rahman Shalabi, who was among the first to be brought to Guantanamo in 2002. Shalabi's hunger strike lasted for nine years, during which time he was fed with a nasogastric tube every day. ${ }^{89}$ Tariq Ba Odah, another detainee captured in 2002, has not been eating voluntarily since 2007 . He is in grave danger of dying despite being force fed, as he has lost almost half of his ideal bodyweight. As many others, Ba Odah has been cleared for release, but still held in detention. According to him, "[p]rotesting by hunger striking is the only way to communicate [to those with freedom] what it means to be unjustly detained, to be put in a cell for over a decade without charge." 90 Ba Odah's attorney has asked a federal judge to order his client's release by reason of his progressive physical and psychological deterioration. The officials, however, are reluctant to agree, as they fear setting a precedent for other detainees, encouraging them to stop eating as well. Instead, Ba Odah's hunger strike is deemed "non-compliant" behavior, and he is being kept in solitary confinement. $^{91}$

What explains such measures from the state against hunger strikers, who are not, albeit symbolically, threatening to harm anyone but themselves? The symbolic 
Published in:

Law, culture and the humanities, 15(2), 516-539.

https://doi.org/10.1177/1743872116650868

dimension of hunger striking as resistance seems to be very strong. From the state's perspective, resistance must be quashed in order to preserve the dominant truth: in Guantanamo Bay, participating in a hunger strike is considered a disciplinary matter and is treated with force. Hunger strikers have been subjected to solitary confinement, and those whose condition has worsened have been force-fed twice daily in restraint chairs. ${ }^{92}$ In response to these measures, the detainees have attempted suicide and rioted, which, in turn, has provoked a response with rubber bullets and pepper spray. ${ }^{93}$ Hunger strikes were also met with a violent response in Turkey: in 1995, 1999, and 2000 the government undertook military operations both inside and outside prisons. In the operation Return to Life in 2000, 30 inmates and two military personnel were killed in 20 prisons, many more were injured, and more than 1000 were forcibly transferred to the F-type prison. ${ }^{94}$

Hunger striking and suicide attempts can also be confronted with discursive tactics. The political aspect of bodily resistance can be defused by altering the vocabulary used to describe it; US officials have described acts of self-harm, such as hunger striking and suicide attempts, as "manipulative self-injurious behavior," "strangulation gestures," and "coordinated efforts to disrupt camp operations." These acts have also been identified as violent acts of war, even as "asymmetrical warfare," which aims to delegitimize self-harm as a form of resistance. ${ }^{95}$

As argued throughout this article, the refugee's relationship with the law/state is 
Published in:

Law, culture and the humanities, 15(2), 516-539.

https://doi.org/10.1177/1743872116650868

different from that of the detainee and the prisoner. For refugees, hunger striking is a way to make their individual existence apparent. There are numerous cases of hunger strikes, lip sewing, and other forms of non-violent, bodily resistance among European refugees. ${ }^{96}$

The official and unofficial refugee camps in Calais, France, the "Calais Jungle," have become a housing site for thousands of refugees, many of them from Syria. The living conditions are completely inadequate: people are living in tents, no proper sanitation facilities are available, and there is a constant lack of food, clothes, and medical care. In 2014, 30 refugees in Calais went on a hunger strike demanding proper housing, sanitation facilities, free movement, proper food, and negotiations between France and the UK to allow the refugees to enter British territory to claim asylum there. ${ }^{97}$ Recently, a group of refugees stranded at the border between Greece and Macedonia went on a hunger strike in protest against a filtering system adopted by some Balkan countries for rejecting those classed as economic migrants without examining each case individually. ${ }^{98}$ And in April 2013 detained refugees at the Amygdaleza camp in Greece went on a hunger strike to protest the conditions of their detention. Another 2000 immigrants held at centers around the country soon joined their strike. ${ }^{99}$ While the Guantanamo detainees and supermax prisoners reject their subjectivities through hunger striking, the refugees whose individual presence has not yet been acknowledged by the state aim at 
Published in:

Law, culture and the humanities, 15(2), 516-539.

https://doi.org/10.1177/1743872116650868

becoming recognized as individuals instead of being dissolved into an anonymous mass.

Regarding the claims made by the hunger strikers, hunger strikes have not perhaps been very effective. But rather than effective in this sense, hunger strikes can be understood as an attempt to call the law out on its hypocrisy: the law grants the Guantanamo detainees the right of Habeas Corpus, yet, by allowing ongoing indefinite detention, robs those rights of their practical meaning; the law claims to provide universal human rights for all, yet in practice favors citizens; the law alters our perception by claiming that solitary confinement in a supermax is not about punishment, but about security; the law provides legal protection, but in practice effectively blocks access to it.

Hunger striking has proved to be a way to contest not only the practices of law, but also its creations: the subjectivities of the detainee, the prisoner, and the refugee. Moreover, it is a way to establish shared realities and communal ties within and beyond the boundaries of the three sites discussed in this article. The sheer number of people participating in hunger strikes is staggering: in 2013 more than 2000 immigrants held in detention centres in Greece went on a hunger strike to denounce the intolerable conditions and to protest the Greek government's decision to extend the detention period to 18 months; the Turkish prisoners' hunger strike over F-type 
Published in:

Law, culture and the humanities, 15(2), 516-539.

https://doi.org/10.1177/1743872116650868

prisons was joined by activists outside prisons, particularly in the Kücük Armutlu neighborhood in Istanbul; ${ }^{100}$ and the Pelican Bay hunger strike in 2013 spread to prisons across California and involved tens of thousands of participants. To return to Cover's argument about torture being aimed at destroying "the victim's normative world and capacity to create shared realities," 101 the prevalence of hunger striking indicates that it indeed is a way to resist torture practices.

\section{A VI. Conclusion}

In the closed facilities discussed in this article, the subject production process involves violent techniques such as torture in the form of enhanced interrogation techniques, solitary confinement, debriefing, poor living conditions, and practices that block access to justice - all practices supported by the law, either explicitly or implicitly. To some extent, the legal claims made by the detainee, the prisoner, and the refugee to contest these practices have been successful, but have failed to bring forth a more fundamental change in their relationship with the state. The hunger strikers, the martyrs, on the other hand, deconstruct their subjectivity by disfiguring it with their own bodies, create new shared realities among them, and force the law to face its own violence. They refuse to be subjectified as enemy combatants, as subjects with reduced protection under the law, as terrorists, as the enemy, as an 
Published in:

Law, culture and the humanities, 15(2), 516-539.

https://doi.org/10.1177/1743872116650868

anonymous mass. The hunger strikers reveal the violence behind the state's power practices by refusing to adopt the reduced subjectivities reserved for them. The hunger striker does not speak the law, since speaking the law requires the hunger striker to appeal to, and thus reproduce, the dominant value system either out of genuine ethical incorporation or for strategic reasons. ${ }^{102}$

Taking the law for all that it does blurs the distinctions between the law and power, the law and politics, and the law and the state. The state, power, and politics are present in the law, just as they are all present in the three sites discussed in this article. Agamben's observation of opposites dissolving into each other is taken here to its logical conclusion: bios and zoe, inside and outside, rule and exception become indistinguishable; there is neither inside nor outside, and there is no reason to try to protect the law from its inherent violence by reproducing the dichotomy of law/force, and thereby outsourcing the law's violence. ${ }^{103}$ Rights are not the same for all. The profound distinction between us and the Other is constantly recreated in legal practices which divide people according to their characteristics and status. The law has not one subject position, but multiple positions for qualitatively different kinds of subjects: the citizen, the prisoner, the asylum seeker, the illegal immigrant, the enemy combatant, the detainee. Any one of us could become subjectified as any one of these. In this sense, the shattered pieces of Homo Sacer exist in all of us. ${ }^{104}$ 
Published in:

Law, culture and the humanities, 15(2), 516-539.

https://doi.org/10.1177/1743872116650868

Throughout this article one of my main claims has been that unlike the subjectivity of the refugee, the subjectivities of the detainee and the prisoner are inseparably accompanied by the notion of danger. This, however, seems to be changing as the refugee is increasingly regarded as a potential security threat in Europe. The terrorist attacks in Paris in November 2015 in which 129 people were killed and hundreds more were wounded is the latest incident resulting in increased suspicion towards refugees and immigrants, as according to initial rumors, some of the suspects had entered Europe as Syrian refugees. It was later confirmed that the attackers were all European Union nationals, but the fear of ISIS fighters infiltrating Europe among refugees persists.

Securitizing the issue of asylum seeking, and perceiving refugees as threat to the ethno-cultural compilation, economic stability, and physical integrity of the state and individuals, is not, in itself, a new phenomenon. ${ }^{105}$ Currently the refugees are predominantly treated as a mass in Europe, as illustrated by the recent EU - Turkey refugee deal. While the EU has assured that every asylum application will be treated individually on a case by case basis, and that there will be no blanket and automatic returns for asylum seekers, Amnesty International has expressed its concern over large-scale forced returns of refugees from Turkey to Syria. ${ }^{106}$ The deportations began practically immediately after the deal came into force. Currently everyone arriving on the Greek islands are facing automatic detention in dire 
Published in:

Law, culture and the humanities, 15(2), 516-539.

https://doi.org/10.1177/1743872116650868

conditions and without access to proper asylum process. ${ }^{107}$ The international medical humanitarian organization Doctors Without Borders has ended its activities in Moria detention center in Lesvos island, because "continuing to work inside would make us complicit in a system we consider to be both unfair and inhumane". ${ }^{108}$

The recent changes in the laws and other state practices concerning the refugee indicate, that the refugee subjectivity is growing increasingly fragmented. ${ }^{109}$ If the aspect of danger becomes an intrinsic feature of the individual refugee subject, it is possible that their treatment starts to increasingly resemble that of the detainee and the prisoner, and that the "dangerous individuals" are screened and singled out from the mass. The refugees are facing a double challenge, as they strive firstly to be recognized as individuals, and secondly to be recognized as genuine refugees deserving humanitarian protection. The examples of subject production techniques discussed in this article illustrate the process in which the violent practices produce the subjects, and how the subjects thus produced affect the practices in turn.

\section{Acknowledgements}

The author acknowledge helpful feedback from Samuli Hurri, Sakari Melander, 


\section{PREPRINT}

Published in:

Law, culture and the humanities, 15(2), 516-539.

https://doi.org/10.1177/1743872116650868

Monica Lopez Lerma and the two anonymous reviewers at Law, Culture, and the

Humanities. This work was supported by the Aili and Brynolf Honkasalo Fund,

Finnish Cultural Foundation, the Olga and Kaarle Oskari Laitinen Foundation, and the Kone Foundation.

${ }^{1}$ Colin Dayan, The Law is a White Dog. How Legal Rituals Make and Unmake Persons (Princeton and Oxford: Princeton University Press, 2013), p. 22.

${ }^{2}$ See e.g. Dayan, The Law is a White Dog, p. 201.

${ }^{3}$ See e.g. Tehila Sagy, "Do Human Rights Transcend Citizenship? Lessons from the Buduburam Refugee Camp," Social \& Legal Studies, 23(2) (2014), pp. 219—220.

${ }^{4}$ See also Costas Douzinas and Adam Gearey, Critical Jurisprudence. The Political Philosophy of Justice (Oxford and Portland Oregon: Hart Publishing, 2005), pp. 9, 17.

${ }^{5}$ Dayan, The Law is a White Dog, p. 201.

${ }^{6}$ Scott Veitch, Law and Irresponsibility: On the Legitimation of Human Suffering (Abingdon:

Routledge-Cavendish, 2007); see also Valerie Kerruish, "Responding to Kruger: the Constitutionality of Genocide," Australian Feminist Law Journal 11 (1998), pp. 65-82.

${ }^{7}$ Robert M. Cover, "Nomos and Narrative," Harvard Law Review 97(4) (1983), p. 7.

${ }^{8}$ Op. cit. 


\section{PREPRINT}

Published in:

Law, culture and the humanities, 15(2), 516-539. https://doi.org/10.1177/1743872116650868

${ }^{9}$ Michel Foucault, Power/Knowledge. Selected Interviews and Other Writings 1972-1977, ed. Colin

Gordon, trans. Colin Gordon, Leo Marshall, John Mepham and Kate Sope (New York: Pantheon Books, 1980), pp. $81-81$.

${ }^{10}$ Michel Foucault, “Omnes et Singulatim: Towards a Criticism of 'Political Reason'. The Tanner Lectures on Human Values," in ed. James D. Faubion, Michel Foucault: Power. Essential Works of Michel Foucault 1954-1984 Vol. 3 (London: Penguin Books, 2002), pp. 298-325; Andrea Mubi Brighenti, "Power, Subtraction and Social Transformation: Canetti and Foucault on the Notion of Resistance,” Distinktion: Scandinavian Journal of Social Theory 12(1) (2011) pp. 57-78.

${ }^{11}$ Michel Foucault, “The Subject and Power," in ed. James D. Faubion, Power. The Essential Works of Michel Foucault 1954-1984 Vol. 3 (London: Penguin Books, 2002), p. 340.

${ }^{12}$ Robert M. Cover, "Violence and the Word," The Yale Law Journal 95 (1986), p. 1603. See also Elaine Scarry, The Body in Pain: The Making and Unmaking of the World (New York: Oxford University Press, 1985).

${ }^{13}$ Cover, "Violence and the Word", pp. 1604-1605.

${ }^{14}$ See Andreja Zevnik, "Becoming-Animal, Becoming-Detainee: Encountering Human Rights Discourse in Guantanamo," Law and Critique 22(2) (2011), pp. 155-169; Colin Dayan, The Law is a White Dog, pp. 26-29.

${ }^{15}$ On interpellation, see Louis Althusser, On Ideology (London \& New York: Verso, 2008).

${ }^{16}$ For legal perspectives on force feeding, see e.g. Joel K. Greenberg, Hunger Striking Prisoners: The Constitutionality of Force-Feeding, Fordham Law Review 51(4) (1983); European Court of Human Rights cases: Nevmerzhitsky v. Ukraine (April 5, 2005) App. No. 54825/00; Pandjikidzé and Others v. Georgia (October 27, 2009) App. No. 30323/02; Özgül v. Turkey (April 16, 1998) App. No. 36589/97; Ciorap v. Moldova (June 19, 2007) App. No. 12066/02; Rappaz v. Switzerland (March 26, 2013) App. No. $73175 / 10$. 


\section{PREPRINT}

Published in:

Law, culture and the humanities, 15(2), 516-539. https://doi.org/10.1177/1743872116650868

${ }^{17}$ Nathan Widder, “Foucault and Power Revisited," European Journal of Political Theory 3(4) (2004), p. 421 .

${ }^{18}$ Patrick Anderson, "To Lie Down to Death for Days: The Turkish Hunger Strike, 2000_2003," Cultural Studies 18(6) (2004), pp. 818, 821.

${ }^{19}$ Cf. Michael Welch, "Guantanamo Bay as a Foucauldian Phenomenon: An Analysis of Penal

Discourse, Technologies, and Resistance," Prison Journal 89(1) (2009), p. 4.

${ }^{20}$ See e.g. John T. Parry, “Torture Nation, Torture Law,” Georgetown Law Journal 97 (2008_-2009) pp. $173-214$.

${ }^{21}$ Gerard A. Hauser, Prisoners of Conscience: Moral Vernaculars of Political, Studies in

Rhetoric/Communication (Columbia, South Carolina: University of South Carolina Press, 2012), p. 86; see Philip G. Zimbardo, The Lucifer Effect: Understanding How Good People Turn Evil (New York: Random House Trade Paperbacks, 2008).

${ }^{22}$ See Joseph J. Margulies, “A Prison Beyond the Law,” Virginia Quarterly Review 80(4) (2004), pp. 37_55; Johan Steyn, “Guantanamo Bay: The Legal Black Hole,” International \& Comparative Law Quarterly 53(1) (2004), pp. 1-15.

${ }^{23}$ Giorgio Agamben, Homo Sacer: Sovereign Power and Bare Life, trans. Daniel Heller-Roazen (Stanford, CA: Stanford University Press 1998), pp. 12, 47.

${ }^{24}$ Leila Brännström, "How I learned to stop worrying and use the legal argument - a critique of Giorgio Agamben's notion of law," No Foundations (2008) p. 31;

Fleur Johns, "Guantanamo Bay and the Annihilation of the Exception," European Journal of International Law 16(4) (2005), p. 617.

${ }^{25}$ David Hicks, who spent five and a half years at Guantanamo, in Jason Leopold, "Exclusive: David Hicks: One of Guantanamo Bay's First Detainees Breaks His Silence,” Truthout, February 15, 2011, 


\section{PREPRINT}

Published in:

Law, culture and the humanities, 15(2), 516-539. https://doi.org/10.1177/1743872116650868

http://www.truth-out.org/news/item/258:exclusive-one-of-guantanamo-bays-first-detainees-breaks-hissilence.

${ }^{26}$ Besides Guantanamo Bay, the US holds thousands - even tens of thousands - more detainees in lesspublicized locations around the world. See "United States of America: Guantanamo and Beyond: The Continuing Pursuit of Unchecked Executive Power," Amnesty International, May 13, 2005, https://www.amnesty.org/en/documents/amr51/083/2005/en/.

${ }^{27}$ See e.g. Brännström, "How I learned to stop worrying and use the legal argument," pp. 25-30; Jennifer K. Elsea and Michael John Garcia, "Enemy Combatant Detainees: Habeas Corpus Challenges in Federal Court," CRS Report for Congress, February 3, 2010, https://fas.org/sgp/crs/natsec/RL33180.pdf. ${ }^{28}$ Spencer Ackerman, "Inbuilt Delays in Case Reviews Make Prospect of Guantánamo Closure Recede," The Guardian, January 11, 2016, http://www.theguardian.com/usnews/2016/jan/11/guantanamo-prisoner-release-delays-review-boards-closure?CMP=fb_gu.

${ }^{29}$ The interrogation techniques were classified either as "standard" or "enhanced" the difference being that the standard techniques did not incorporate physical or substantial psychological pressure, while the enhanced techniques did. Miles Daugherty, "Perspectives on Enhanced Interrogation Techniques," Congressional Research Service (2015), https://www.fas.org/sgp/crs/intel/R43906.pdf;

George Tenet, "Guidelines on Interrogations Conducted Pursuant to the (redacted)," January 28, 2003, https://www.aclu.org/files/torturefoia/released/082409/olcremand/2004olc12.pdf.

${ }^{30}$ Cover "Violence and the Word," p. 1603.

${ }^{31}$ Scarry, The Body in Pain, pp. 29-30.

${ }^{32}$ Prison chaplain John Clay at Preston House of Correction, in Potter 1993, p. 46 as cited in Peter Scharff Smith, "The Effects of Solitary Confinement on Prison Inmates: A Brief History and Review of the Literature," Crime \& Justice 34(1) (2006), p. 461. 


\section{PREPRINT}

Published in:

Law, culture and the humanities, 15(2), 516-539. https://doi.org/10.1177/1743872116650868

33 “Transcript (Full) Joint Legislative Informational Hearing on Solitary Confinement. California, Oct. 9, 2013. Co-Chaired Sen. Loni Hancock, Assemblyman Tom Ammiano. Housing in CA's Prisons Today: Describing the Physical \& Programming Conditions of Segregated Confinement, California State Legislature," pp.1-4, 19, https://prisonerhungerstrikesolidarity.files.wordpress.com/2013/12/20131009_hearing_transcript.pdf.

34"Security Housing Units Fact Sheet," The California Department of Corrections and Rehabilitation, October 2013, http://www.cdcr.ca.gov/stg/docs/Fact\%20Sheet-SHU\%20with\%20photos.pdf.

35 “Transcript of Joint Legislative Informational Hearing," pp. 5-6; ”Security Housing Units Fact Sheet".

36 "Security Housing Units Fact Sheet”.

${ }^{37}$ Parry, "Torture Nation, Torture Law," p.1027.

${ }^{38}$ Scharff Smith, "The Effects of Solitary Confinement on Prison Inmates," p. 449.

39 “USA. The Edge of Endurance. Prison Conditions in California's Security Housing Units” Amnesty International (London: Amnesty International Publications, 2012), pp. 33-34, http://www.amnestyusa.org/research/reports/the-edge-of-endurance-prison-conditions-in-california-ssecurity-housing-units; "Security Threat Group Prevention, Identification and Management Strategy," (draft) The California Department of Corrections and Rehabilitation, June 29, 2012, https://assets.documentcloud.org/documents/452638/cdcr-reforms-7-0.pdf; see also "Security Threat Group Identification, Prevention, and Management Instructions Memorandum," California Department of Corrections and Rehabilitation, October 12, 2012, http://www.cdcr.ca.gov/stg/docs/Security-ThreatGroup-Prevention-ID-Mgmt-Inst-Memo-1.pdf; and "Torture: The use of Solitary Confinement in US Prisons," Center for Constitutional Rights, May 31, 2012, http://ccrjustice.org/solitary-factsheet. 40 "Security Housing Units Fact Sheet". 


\section{PREPRINT}

\section{Published in:}

Law, culture and the humanities, 15(2), 516-539. https://doi.org/10.1177/1743872116650868

\footnotetext{
${ }^{41}$ According to the strategy plan, suspects and monitored supplement the current classification of gang members, associates, and inactives, thereby refining the definition and identification of the categories.
} According to the revised SHU placement criteria, STG-I members are placed in SHUs based on their confirmation as a gang member. However, STG-I associates are not routinely placed in SHUs unless they are believed to have engaged in serious disciplinary behavior and/or displayed "gang behavior." Prisoners associated with security threat groups classified as less dangerous are placed in SHUs only if they "engage in repetitive criminal gang behavior." Security Threat Group Prevention, Identification and Management Strategy (Draft)" pp. 7-9; 12, 16-20, 27-28.

42 “Security Threat Group Prevention, Identification and Management Strategy," p. 27-33.

${ }^{43}$ NARN Collective Think Tank, "Declining a Deal with the Devil: Coercive Journaling Required to ‘Step Down’ from Solitary Confinement,' San Francisco Bay View National Black Newspaper, January 30, 2014, http://sfbayview.com/2014/01/declining-a-deal-with-the-devil-coercive-journaling-requiredto-step-down-from-solitary-confinement/; Michael R. Dorrough, J. H Denham, Kambui Robinson and Jabari Scott, "Open Letter to Assemblyman Tom Ammiano from Prisoners in Solitary Confinement in Corcoran State Prison,” San Francisco Bay View National Black Newspaper, May 23, 2014, http://sfbayview.com/2014/05/open-letter-to-assemblyman-tom-ammiano-from-prisoners-in-solitaryconfinement-in-corcoran-state-prison/; “Security Threat Group Identification, Prevention, and Management Instructions Memorandum".

${ }^{44}$ David Garland, "'Governmentality' and the Problem of Crime: Foucault, Criminology, Sociology," Theoretical Criminology 1(2) (1997), pp.173-214.

${ }^{45}$ Michel Foucault, Discipline and Punish: The Birth of the Prison, trans. Alan Sheridan (London: Penguin Books, 1991), pp. 281; Samuli Hurri, Birth of the European Individual. Law, Security, Economy (New York: Routledge, 2014), pp. 164-165. 


\section{PREPRINT}

\section{Published in:}

Law, culture and the humanities, 15(2), 516-539. https://doi.org/10.1177/1743872116650868

\footnotetext{
${ }^{46}$ This term was used by the European Court of Human Rights with respect to the refugees' situation in the cases M.S.S. v. Belgium and Greece (January 21, 2011) App. No.30696/09; Budina v. Russia (June 18, 2009) App. No. 45603/05; "State responsibility [under Article 3] could arise for 'treatment' where an applicant, in circumstances wholly dependent on State support, found herself faced with official indifference when in a situation of serious deprivation or want incompatible with human dignity". See also Gina Clayton, “Asylum Seekers in Europe: M.S.S. v. Belgium and Greece,” Human Rights Law Review 11(4) (2011), pp. 767, 769.
}

${ }^{47}$ An Afghan man called Farhad to Anna Giralt in an interview, in "Refugees Describe Dire Conditions in Migrant Detention Centres," EnetEnglish, February 21, 2014, http://www.enetenglish.gr/?i=news.en.article\&id=1775.

${ }^{48}$ Agamben, Homo Sacer, p. 133.

${ }^{49}$ Simon Behrman, "Accidents, Agency and Asylum: Constructing the Refugee Subject," Law and Critique 25(3) (2014), pp. 249-250.

${ }^{50}$ However, the majority of the refugees stay in neighboring countries, and only approximately $10 \%$ of them end up in Europe. In January 2016 the number of Syrian refugees registered by the UNHCR in Egypt, Iraq, Jordan, and Lebanon was over 2 million, in Turkey 1.9, and in North Africa more than 26 700. “Syria Regional Refugee Response," Inter-agency information sharing portal, The UN Refugee Agency, 2016, http://data.unhcr.org/syrianrefugees/regional.php.

${ }^{51}$ Laurence Norman and Emre Peker, "European Union Reaches Deal With Turkey on Migration," The Wall Street Journal, November 29, 2015, http://www.wsj.com/articles/eu-turkey-strike-deal-to-stemflow-of-refugees-1448803008; "Refugees and Internally Displaced Persons," Humanitarian Aid and Civil Protection Fact sheet, European Commission, 2015, http://ec.europa.eu/echo/files/aid/countries/factsheets/thematic/refugees_en.pdf. 


\section{PREPRINT}

Published in:

Law, culture and the humanities, 15(2), 516-539. https://doi.org/10.1177/1743872116650868

52 “Refugees Describe Dire Conditions in Migrant Detention Centres," EnetEnglish, February 21, 2014, http://www.enetenglish.gr/?i=news.en.article\&id=1775; Paul McDonough and Evangelia Tsourdi, Putting Solidarity to the Test: Assessing Europe's Response to the Asylum Crisis in Greece (Geneva: UNHCR: Policy Development and Evaluation Service, 2012); Migration and Asylum: Mounting Tensions in the Eastern Mediterranean, Parliamentary Assembly: Committee on Migration, Refugees and Displaced Persons, 23 January 2013, http://assembly.coe.int/nw/xml/XRef/Xref-XML2HTMLen.asp?fileid=19467\&lang=en; "Report of the Special Rapporteur on torture and other cruel, inhuman or degrading treatment or punishment, Manfred Nowak - Addendum - Mission to Greece," UN Human Rights Council April 21, 2011, https://documents-ddsny.un.org/doc/UNDOC/GEN/G11/129/68/PDF/G1112968.pdf?OpenElement; Izabella Majcher and Michael Flynn, Immigration Detention in Greece (Geneva: Global Detention Project Global Migration Centre Graduate Institute of International and Development Studies, 2014).

53 "Europe's refugee crisis - a visual guide," The Guardian, September 25, 2015, http://www.theguardian.com/world/ng-interactive/2015/sep/18/latest-developments-in-europes-refugeecrisis-a-visual-guide.

54 "Bulgaria: 'Inhuman Conditions' Spark Protest at Refugee Camp,” Amnesty International, November 19, 2013, https://www.amnesty.org/en/latest/news/2013/11/bulgaria-inhuman-conditions-spark-protestrefugee-camp/.

55 See e.g. McDonough and Tsourdi, Putting Solidarity to the Test, pp. 3-6.

${ }^{56}$ Directive 2013/32/EU of the European Parliament and of the Council of 26 June 2013 on common procedures for granting and withdrawing international protection; preceding Council Directive 2005/85/EC of 1 December 2005 on minimum standards on procedures in Member States for granting and withdrawing refugee status. 


\section{PREPRINT}

Published in:

Law, culture and the humanities, 15(2), 516-539. https://doi.org/10.1177/1743872116650868

57 “Unwelcome Guests. Greek Police Abuses of Migrant in Athens," Human Rights Watch, June 12, 2013, https://www.hrw.org/report/2013/06/12/unwelcome-guests/greek-police-abuses-migrants-athens. ${ }^{58}$ See the discussion on crimmigration; Juliet Stumpf, "Crimmigration. Encountering the Leviathan," in Sharon Pickering and Julie Ham eds., The Routledge Handbook on Crime and International Migration. (London and New York: Routledge, 2014), pp. 237-250; see also Christina Elefteriades Haines and Anil Kalhan, "Detention of Asylum Seekers en Masse: Immigration Detention in the United States," in Stephanie J. Silverman and Amy Nethery eds., Immigration Detention: The Migration Policy and its Human Impact. (Abingdon and New York: Routledge, 2015), p. 69-78; Stephanie J. Silverman and Amy Nethery, "Understanding Immigration Detention and its Human Impact," in Stephanie J.

Silverman and Amy Nethery eds., Immigration Detention: The Migration Policy and its Human Impact. (Abingdon and New York: Routledge, 2015), p. 2-3; Izabella Majcher and Michael Flynn, “Immigration Detention in Greece," Global Detention Project, March 2014, http://www.globaldetentionproject.org/sites/default/files/fileadmin/docs/Greece_report.pdf.

${ }^{59}$ Directive 2008/115/EC of the European Parliament and of the Council of 16 December 2008 on common standards and procedures in Member States for returning illegally staying third-country nationals.

${ }^{60}$ Melanie Griffiths, “'A Proud Tradition'? Immigration Detention in the United Kingdom,” in Stephanie J. Silverman and Amy Nethery eds., Immigration Detention: The Migration Policy and its Human Impact. (Abingdon and New York: Routledge, 2015), p. 16; Angeli 2014 as cited in Majcher and Flynn, Immigration Detention in Greece, p. 7.

61 "Study on the Phenomena of Torture, Cruel, Inhuman or Degrading Treatment or Punishment in the World, Including an Assessment of Conditions of Detention, "Report of the Special Rapporteur on torture and other cruel, inhuman or degrading treatment or punishment, Manfred Nowak - Addendum Mission to Greece"; "Report of the Special Rapporteur on the human rights of migrants, François 


\section{PREPRINT}

Published in:

Law, culture and the humanities, 15(2), 516-539.

https://doi.org/10.1177/1743872116650868

Crépeau on his mission to Greece (25 November to 3 December 2012)," UN Human Rights Council, April 17, 2013; McDonough and Tsourdi, Putting Solidarity to the Test; Bill Frelick, "Stuck in a Revolving Door. Iraqis and Other Asylum Seekers and Migrants at the Greece/Turkey Entrance to the European Union," Human Rights Watch, November 2008, https://www.hrw.org/report/2008/11/26/stuck-revolving-door/iraqis-and-other-asylum-seekers-andmigrants-greece/turkey; "Asylum in the European Union. A Study of the Implementation of the Qualification Directive," The United Nations Refugee Agency, 2007, http://www.unhcr.org/47302b6c2.html.

${ }^{62}$ See Sagy, “Do Human Rights Transcend Citizenship?” pp. 215-236; On refugees' agency within the legal field, see e.g. Elizabeth Holzer, "What Happens to Law in a Refugee Camp?" Law \& Society Review 47(4) (2013), pp. 837-872.

${ }^{63}$ Se e.g. "Denmark Advertises How Bad the Country is to Refugees," EurActive, September 8, 2015, http://www.euractiv.com/sections/justice-home-affairs/denmark-advertises-how-bad-country-refugees317417; Natalie Isley, "Norway Launches Social Media Campaign to Discourage Refugees from Entering," Newsweek, February 11, 2015, http://europe.newsweek.com/norway-launches-social-mediacampaign-discourage-refugees-entering-335842.

${ }^{64}$ See e.g. Robyn Sampson, "Mandatory, Non-reviewable, Indefinite: Immigration Detention in Australia," in Stephanie J. Silverman and Amy Nethery eds., Immigration Detention: The Migration Policy and its Human Impact (Abingdon and New York: Routledge, 2015), p. 104-113.

${ }^{65}$ Azadeh Dastyari, "Breaching International Law: Immigration Detention in Guantanamo Bay, Cuba," in Stephanie J. Silverman and Amy Nethery eds., Immigration Detention: The Migration Policy and its Human Impact (Abingdon and New York: Routledge, 2015), p. 96-99.

${ }^{66}$ No. 92-344, June 21, 1993.

${ }^{67}$ Op. cit. 


\section{PREPRINT}

Published in:

Law, culture and the humanities, 15(2), 516-539. https://doi.org/10.1177/1743872116650868

${ }^{68}$ John T. Parry, “Torture Nation, Torture Law,” p. 1030; Harold Hongju Koh, “America's Offshore Refugee Camps," (Human Rights International Law Symposium, University of Richmond Law Review 29(1) (1994), pp 139-173; Haitian Centers Council, Inc. v. Sale 509 US 155, 1993.

${ }^{69}$ See Banu Bargu, Starve and Immolate: The Politics of Human Weapons (New York: Columbia University Press, 2014), pp. 273-274.

${ }^{70}$ See also Court of Justice of the European Union rulings in joint cases C-411/10 (N.S.) and C-493/10 (M.E.) and the European Court of Human Rights cases S.D. v. Greece (June 11, 2009) App. No(s).

53541/07; R.U. v. Greece (June 7, 2011) App. No(s). 2237/08, in which the court found that conditions at the Soufli Border Guard Station amounted to degrading treatment.

${ }^{71}$ Council Regulation (EC) No 343/2003 of 18 February 2003 establishing the criteria and mechanisms for determining the Member State responsible for examining an asylum application lodged in one of the Member States by a third-country national.

${ }^{72}$ Gina Clayton, “Asylum Seekers in Europe: M.S.S. v. Belgium and Greece,” p. 765.

${ }^{73}$ Laurens Lavrysen, "M.S.S. v. Belgium and Greece (2): The Impact on EU Asylum Law," Strasbourg Observers, February 24, 2011, http://strasbourgobservers.com/2011/02/24/m-s-s-v-belgium-and-greece2-the-impact-on-eu-asylum-law/.

${ }^{74}$ Ashker v. Governor of California No. 4:09-cv-05796-CW (N.D. California, 2012) Settlement Agreement, http://ccrjustice.org/sites/default/files/attach/2015/09/2015-09-01-ashker-

Settlement_Agreement.pdf.

${ }^{75}$ No. 03-334, June 28, 2004.

${ }^{76}$ No. 03-6696, June 28, 2004.

${ }^{77}$ No. 05-184, June 29, 2006.

${ }^{78}$ No. 06-1195, June 12, 2008.

${ }^{79}$ Anderson, "'To Lie Down to Death for Days'," pp. 816-846. 


\section{PREPRINT}

\section{Published in:}

Law, culture and the humanities, 15(2), 516-539. https://doi.org/10.1177/1743872116650868

\footnotetext{
${ }^{80}$ Anderson, "'To Lie Down to Death for Days'," pp. 816 - 846; see also Bargu, Starve and Immolate.

${ }^{81}$ Anderson, "'To Lie Down to Death for Days'," p. 840.

${ }^{82}$ Op. cit.

83 “Ashker v. Governor of California," the Center for Constitutional Rights, https://ccrjustice.org/home/what-we-do/our-cases/ashker-v-brown.

${ }^{84}$ The hunger strike initiated a hearing conducted by the Joint Public Safety Committee of the
} California Legislature. The key issues in the hearings were the confinement conditions and the effects of long-term solitary confinement, see "Transcript of Joint Legislative Informational Hearing”.

85 The evidence used in the gang validation process may include symbols, such as hand signs, tattoos, distinctive clothing, and graffiti which have been identified with a particular gang; information from staff, informants, legal documents, and debriefing reports; written material such as membership lists, gang constitutions, organizational structures, and training material; photographs with gang connotations; visits from persons who are documented as willfully promoting, furthering, or assisting gangs and their activities; telephone conversations; conversations between inmates; greeting cards; self-admission; and offences in which the circumstances suggest that they were committed in association with a gang.

“Security Threat Group Prevention, Identification and Management Strategy,” pp. 15-20.

${ }^{86}$ See e.g. Joe A'Jene Valentine, ’Review Board Suggests Pelican Bay Prisoner Stop Political Writing for Favorable Placement,” Bay View, National Black Newspaper, May 13, 2014, http://sfbayview.com/2014/05/review-board-suggests-pelican-bay-prisoner-stop-political-writing-forfavorable-placement/.

${ }^{87}$ Law, "Pelican Bay Prison: One Year Later, Policy Remains 'Debrief or Die"; Rory Carroll, “California Prisoners Launch Biggest Hunger Strike in State’s History,” The Guardian, July 9, 2013, http://www.theguardian.com/world/2013/jul/09/california-prisoners-hunger-strike. 


\section{PREPRINT}

\section{Published in:}

Law, culture and the humanities, 15(2), 516-539. https://doi.org/10.1177/1743872116650868

${ }^{88}$ Welch, “Guantanamo Bay as a Foucauldian Phenomenon”, p. 20; ”Mass Suicide Bid at Guantanamo Revealed," The Sydney Morning Herald, January 25, 2005, http://www.smh.com.au/news/GlobalTerrorism/Mass-suicide-bid-at-Guantanamo-revealed/2005/01/25/1106415554358.html; “Guantanamo Guards Try to Break Hunger Strike,” Al-Jazeera, April 15, 2013, http://www.aljazeera.com/news/americas/2013/04/2013413184417804493.html ; Robert Johnson, "Unclassified Document Shows How the Guantanamo Hunger Strike Has Grown Worse and Worse," Business Insider, May 1, 2013, http://www.businessinsider.com/unclassified-guantanamo-hunger-strikedocument-2013-5?IR=T; Matt Williams, “Guantánamo Hunger Strikers make Up Half of Inmate Population, Officials Say,” The Guardian, April 21, 2013, http://www.theguardian.com/world/2013/apr/21/guantanamo-bay-hunger-strike-half-inmates. 89 “Guantánamo prisoner on nine-year hunger strike will be released,” June 26, 2015, http://www.theguardian.com/us-news/2015/jun/26/guantanamo-prisoner-hunger-strike-released-saudiarabia.

${ }^{90}$ Jennifer Fenton, “Guantanamo Hunger Striker Nearing Death,” Al Jazeera, August 12, 2015, http://www.aljazeera.com/indepth/features/2015/08/guantanamo-hunger-striker-nearing-death150812101059995.html.

${ }^{91}$ Op. cit; Charlie Savage, “Guantanamo Hunger Striker's Petition Divides Officials,” The New York Times, August 7, 2015, http://www.nytimes.com/2015/08/08/us/guantanamo-hunger-strikers-petitiondivides-officials.html.

${ }^{92}$ See e.g. Andy Worthington, "Breakthrough on Guantanamo: Judge Orders US Government to Stop Force-Feeding Syrian Prisoner and to Preserve Video Evidence,” May 17, 2014, http://www.andyworthington.co.uk/2014/05/17/breakthrough-on-guantanamo-judge-orders-usgovernment-to-stop-force-feeding-syrian-prisoner-and-to-preserve-video-evidence/. 


\section{PREPRINT}

Published in:

Law, culture and the humanities, 15(2), 516-539. https://doi.org/10.1177/1743872116650868

93 “Guantanamo: Three Years of Lawlessness. Detainees Still Held Indefinitely Without Basic Rights” Human Rights Watch, January 10, 2005, https://www.hrw.org/news/2005/01/10/guantanamo-threeyears-lawlessness; “Guantanamo: Detainee Accounts,” Human Rights Watch, October 26, 2004, https://www.hrw.org/legacy/backgrounder/usa/gitmo1004/; Welch, “Guantanamo Bay as a Foucauldian Phenomenon,” pp. 3-20; James Risen and Tim Golden, “3 Prisoners Commit Suicide at Guantánamo," The New York Times, June 11, 2006, http://www.nytimes.com/2006/06/11/us/11gitmo.html?_r=3\& . 94 Patrick Anderson, '’'To Lie Down to Death for Days'," pp. 820, 837.

95 See e.g. "Guantanamo Suicides 'Acts of War'," BBC News, June 11, 2006, http://news.bbc.co.uk/2/hi/5068606.stm ; Jackie Northam, ”Guantanamo Detainees Attempted Mass Suicide in 2003," National Public Radio, January 24, 2005, http://www.npr.org/templates/story/story.php?storyId=4464452; Bargu, Starve and Immolate, pp. 1112.

96 Jenny Edkins and Véronique Pin-Fat, "Through the Wire: Relations of Power and Relations of Violence," Millennium 34(1) (2005), pp. 1-24; cf. Patricia Owens, "Reclaiming 'Bare Life? Against Agamben on Refugees," International Relations 23(4) (2009), pp. 577-578.

97 "Introduction to Calais," https://calaismigrantsolidarity.wordpress.com/introduction-to-calais/ (last accessed April 22, 2016) Calais Migrant Solidarity; "Message from the Hunger Strikers," Calais Migrant Solidarity, June 17, 2014, https://calaismigrantsolidarity.wordpress.com/tag/hunger-strike/. ${ }^{98}$ Anaella Safdarm, "Refugees Stranded by Recent Decision by Balkan Nations to Screen Refugees by Country, not Merit, Go on Hunger Strike,” Al Jazeera, November 24, 2015, http://www.aljazeera.com/news/2015/11/refugees-hunger-strike-greece-macedonia-border151123152724415.html. 


\section{PREPRINT}

\section{Published in:}

Law, culture and the humanities, 15(2), 516-539. https://doi.org/10.1177/1743872116650868

\footnotetext{
${ }^{99}$ Stefan Steinberg, "Protests at Greek Detention Camp Highlight State Violence against Immigrants in Europe," World Socialist Web Site, August 13, 2013, https://www.wsws.org/en/articles/2013/08/13/greea13.html.

${ }^{100}$ Anderson, "To Lie Down to Death for Days," p. 819.

${ }^{101}$ Robert M. Cover, "Violence and the Word," p. 1603.

102 Ben Crewe, "Power, Adaptation and Resistance in a Late-modern Men's Prison" British Journal of
} Criminology 47(2) (2007), p. 275.

${ }^{103}$ See Johns, "Guantanamo Bay and the Annihilation of the Exception," pp. 620—623, 628 —634; cf. Brännström, "How I Learned to Stop Worrying and use the Legal Argument,” pp. 32-33.

${ }^{104}$ Agamben, Homo Sacer, p. 73.

${ }^{105}$ Barry Buzan, Ole Wæver, Jaap de Wilde, Security: A New Framework for Analysis (London: Lynne Reinner, 1998); Scott D. Watson, "Manufacturing Threats: Asylum Seekers as Threats or Refugees?" Journal of International Law and International Relations, 3(1) (2007), pp. 95-117.

106 “European Commission Fact Sheet: EU-Turkey Agreement: Questions and Answers,” European Commission, March 19, 2016, http://europa.eu/rapid/press-release_MEMO-16-963_en.htm;

“Turkey: Illegal mass returns of Syrian refugees expose fatal flaws in EU-Turkey deal,” Amnesty International, April 1, 2016, https://www.amnesty.org/en/press-releases/2016/04/turkey-illegal-mass-returns-of-syrian-refugeesexpose-fatal-flaws-in-eu-turkey-deal/

107 “Greece: Refugees detained in dire conditions amid rush to implement EU-Turkey deal,” Amnesty International, April 7, 2016,

https://www.amnesty.org/en/latest/news/2016/04/greece-refugees-detained-in-dire-conditions-amidrush-to-implement-eu-turkey-deal/. 


\section{PREPRINT}

Published in:

Law, culture and the humanities, 15(2), 516-539.

https://doi.org/10.1177/1743872116650868

108 "Greece: MSF ends activities inside the Lesvos 'hotspot'," Medecins sans Frontiers, March 22,

2016, http://www.msf.org/article/greece-msf-ends-activities-inside-lesvos-

$\%$ E2\%80\%9Chotspot\%E2\%80\%9D.

109 The fragmentation of refugee subjectivity, see Sandro Mezzadra and Brett Neilson, Border as

Method, or, the Multiplication of Labor, (Durham and London: Duke University Press, 2013);

Magdalena Kmak, "Between Citizen and Bogus Asylum Seeker: Management of Migration in the EU

through the Technology of Morality," Social Identities 21(4) (2015), pp. 373-394. 